\title{
Zooplankton feeding behavior and particle selection in natural plankton assemblages containing toxic Alexandrium spp.
}

\author{
Gregory J. Teegarden ${ }^{1, *}$, Robert G. Campbell ${ }^{2}$, Edward G. Durbin ${ }^{2}$ \\ ${ }^{1}$ Bowdoin College, 6700 College Station, Brunswick, Maine 04011, USA \\ ${ }^{2}$ Graduate School of Oceanography, University of Rhode Island, Narragansett, Rhode Island 02882, USA
}

\begin{abstract}
Laboratory experiments suggest that toxic Alexandrium spp. cells are unpalatable to zooplankton grazers, and that toxic cells should be selectively avoided by zooplankton when feeding in mixtures of different prey species. Such avoidance, if practised in the wild, might contribute to harmful bloom formation by reducing losses of Alexandrium spp. due to grazing. In the spring of 1998 and 1999, during 'red tide' outbreaks in the southwestern Gulf of Maine, weekly experiments were performed using field collected natural water samples with ambient phytoplankton and dominant mesozooplankton grazers. The feeding response of Acartia hudsonica, Semibalanus balanoides nauplii, and Calanus finmarchicus was tested during various weeks in natural water samples with low concentrations of Alexandrium spp. $\left(\sim 1000\right.$ cells $1^{-1}$, typical natural concentrations for this region). Semibalanus sp. nauplii consistently avoided toxic Alexandrium spp. and other dinoflagellates. C. finmarchicus selectively fed on diatoms when they were abundant, and fed non-selectively on all dinoflagellates (except Ceratium spp.) when the spring bloom declined and dinoflagellates dominated. A. hudsonica non-selectively cleared Alexandrium spp. throughout the study periods. During spring Alexandrium spp. bloom formation, if non-selective grazers such as A. hudsonica dominate the zooplankton, Alexandrium spp. losses from grazing depend on grazer abundance (biomass); if selective feeders such as $S$. balanoides nauplii dominate, then Alexandrium spp. benefits from reduced grazing losses relative to alternative prey.
\end{abstract}

KEY WORDS: Alexandrium $\cdot$ Paralytic shellfish poisoning $\cdot$ Selective feeding $\cdot$ Zooplankton grazing

\section{INTRODUCTION}

Toxic Alexandrium spp. (predominantly Alexandrium fundyense Balech) in the southwestern Gulf of Maine produce potent neurotoxins known as paralytic shellfish poisoning (PSP) toxins. Harmful Alexandrium spp. blooms in this region are seldom monospecific. Blooms initiate from benthic resting cysts during the early spring (Anderson \& Morel 1979); at this time, diatoms (Skeletonema costatum, Thalassiosira spp., and Chaetoceros spp.) usually dominate the local flora (authors' unpubl. obs.). As Alexandrium spp. proliferation progresses, total abundance of diatoms often

*E-mail: gteegard@bowdoin.edu declines and dominant species shift, while dinoflagellate and other flagellate populations increase, typical of phytoplankton succession processes (Smayda 1980). Thus Alexandrium spp. and other dinoflagellates may form a larger proportion of the total phytoplankton and therefore of prey available to zooplankton. This may present a problem for some zooplankton grazers, as it has been reported that toxic Alexandrium spp. are unpalatable food for some zooplankton species (Turriff et al. 1995, Teegarden 1999).

The feeding behavior of zooplankton during Alexandrium spp. bloom development is not well understood. Experimental field studies published to date, conducted in salt ponds of Cape Cod, Massachusetts, have used natural seawater treatments enriched with mod- 
erate to high Alexandrium spp. cell concentrations (Turner \& Anderson 1983, Watras et al. 1985). These studies concluded that zooplankton abundance was the primary factor affecting rates of Alexandrium spp. removal. Turner \& Anderson (1983) noted that the copepod Acartia hudsonica fed on tintinnid ciliates at higher rates than on co-occurring phytoplankton, but it was not reported in either study whether toxic Alexandrium spp. were selectively avoided or consumed relative to ambient non-toxic phytoplankton.

If zooplankton grazers in natural environments avoid Alexandrium spp., then selective feeding might contribute to bloom development by reducing grazing pressure. Laboratory experiments have established that many copepod species are capable of selective feeding. Discrimination of food particles may be based on size (Frost 1972, 1977), concentration (Lam \& Frost 1976, Price \& Paffenhöfer 1986), and quality (Paffenhöfer \& Van Sant 1985, Van Alstyne 1986, Cowles et al. 1988). Recently it has been shown that the presence of neurotoxic compounds such as saxitoxin can affect particle selection and discrimination (Turriff et al. 1995, Shaw et al. 1997, Teegarden 1999), but such toxins may not always trigger selective feeding responses (Teegarden \& Cembella 1996, Teegarden 1999).

Evidence for selective feeding of copepods in field studies is more equivocal. Selection based on particle size (Cowles 1979, Bautista \& Harris 1992) and quality (Morey-Gaines 1980, Gifford \& Dagg 1988) has been suggested, but the literature contains numerous examples of non-selective feeding in natural situations, even when discrimination might be expected to be due to differences in food quality (e.g., Huntley 1981, Turner \& Tester 1989).

We determined zooplankton feeding rates on natural plankton assemblages during the spring of 1998 and of 1999. We were particularly interested in the grazing response during bloom initiation, when Alexandrium

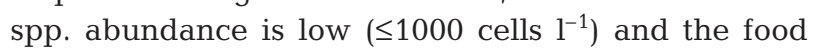
complex is dominated by alternative prey, principally diatoms from the declining spring bloom. One objective was to test the hypothesis that, if zooplankton feeding is selective, such selective feeding should result in lower rates of Alexandrium spp. removal relative to the ambient phytoplankton prey. The study site was the Casco Bay region of the western Gulf of Maine, an area subject to recurring blooms of toxic Alexandrium spp. From late April to early June 1998, a moderate bloom of Alexandrium spp. developed and then declined in the study region. In 1999, Alexandrium spp. cells appeared in low numbers $(\leq 1000$ cells $\mathrm{l}^{-1}$ ) in early May, but fell to background levels by the end of the month. Blooms contained predominantly Alexandrium cf. fundyense, but possibly also contained A. ostenfeldii (see 'Material and methods'); hereafter Alexandrium spp. is used. Field sampling of phytoplankton and zooplankton was coupled with grazing experiments using wild zooplankton and natural water samples (occasionally spiked with low con-

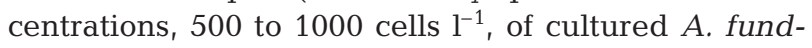
yense clone GTCA 28).

\section{MATERIALS AND METHODS}

Zooplankton and phytoplankton collection. Sampling cruises were conducted weekly from April 20 to June 10, 1998 and April 27 to June 15, 1999, on the RV 'Nucella' of the Darling Marine Center, University of Maine. In 1998, 4 stations were located near the mouth of the Kennebec River: (1) the Damariscotta River estuary, (2) Newagen (Boothbay Harbor), (3) Head Beach, and (4) Cundy's Harbor. These inshore stations had water depths of 10 to $15 \mathrm{~m}$. An additional offshore station (Stn 0) at the mouth of Sheepscot Bay, $60 \mathrm{~m}$ water depth, was sampled in Weeks 6, 7, and 8. Cundy's Harbor ( $\operatorname{Stn} 4,43^{\circ} 47.45^{\prime} \mathrm{N}, 69^{\circ} 53.32^{\prime} \mathrm{W}$ ) was selected as the primary location from which experimental materials should be collected, since historically this location has had high PSP toxicity early in the spring bloom season. Offshore Stn $0\left(43^{\circ} 45.81^{\prime} \mathrm{N}, 69^{\circ} 41.55 \mathrm{~W}\right)$ was incorporated when it became clear that Alexandrium spp. was also proliferating offshore (from the work of the ECOHAB-Gulf of Maine group under Dr D. M. Anderson, WHOI, pers. comm.). In 1999, experiments were conducted with materials from Cundy's Stn 4 and an offshore station (Stn 01, $60 \mathrm{~m}$ depth, $43^{\circ} 38.03^{\prime} \mathrm{N}$, $69^{\circ} 51.14^{\prime} \mathrm{W}, 3$ nautical miles from Cundy's Harbor).

Vertical temperature and salinity profiles were taken with a (Beckman RS5-3 portable thermometer/salinometer Beckman Coulter Inc., Fullerton, CA, USA), and upper water column chlorophyll was characterized by pumping water from depths of $20 \mathrm{~m}$ to the surface with a Teel centrifugal pump (model IP811A, Dayton Electric Mfg. Co., Niles, IL, USA) through a $2 \mathrm{~cm}$ inner diameter (ID) hose to a Turner Designs model 10 fluorometer (Turner Designs Inc., Sunnyvale, CA, USA) equipped with a flow-through cell. If a chlorophyll maximum layer was observed, bottle casts were used to collect water from the layer for experimental purposes; if no maximum layer was found, surface water was collected. Water was stored in $20 \mathrm{l}$ carboys in a large cooler. Large zooplankton were collected with a $303 \mu \mathrm{m}$ net oblique tow from approximately $10 \mathrm{~m}$ to the surface at inshore stations and $30 \mathrm{~m}$ to the surface at offshore stations. Animals were diluted and stored in $4 \mathrm{l}$ jars in coolers during transportation to the laboratory at the Darling Marine Center, approximately $1 \mathrm{~h}$.

Experimental procedure. Upon return to laboratory facilities, zooplankton samples were examined and the 
dominant taxa identified. At the inshore stations, Acartia hudsonica Pinhey was the dominant zooplankton species $\left(10^{2}\right.$ to $10^{5}$ copepodites $\left.\mathrm{m}^{-3}\right)$ in the spring of 1998 and of 1999, while nauplii of the barnacle Semibalanus balanoides $\mathrm{L}$. were abundant $\left(10^{3}\right.$ to $\left.10^{4} \mathrm{~m}^{-3}\right)$ or co-dominant at most stations from April to mid-May. At offshore Stn 0, Calanus finmarchicus Gunnerus was common $\left(>10^{2} \mathrm{~m}^{-3}\right)$.

Water samples for grazing experiments were prepared by reverse filtering $20 \mathrm{l}$ of water through a $250 \mu \mathrm{m}$ mesh to remove large grazers. Some protozoa, notably ciliates, were included in the samples and may have grazed some of the available food, but their abundance was low $\left(\leq 100 \mathrm{l}^{-1}\right)$, and attempts to remove such protozoa would have inevitably caused unacceptable changes in the ambient prey field (e.g., removal of Chaetoceros socialis colonies). Furthermore, protozoa are a natural food source for larger grazers such as copepods, so their presence was desirable.

Alexandrium fundyense was previously reported as the dominant or sole species of Alexandrium in the Casco Bay region of the Gulf of Maine (Anderson 1997). More recent evidence (Dietz \& Townsend 2000) has shown that $A$. ostenfeldii may also be present, although measured abundance is $<10 \%$ of total Alexandrium spp. abundance from our study. Alexandrium spp. from water samples were not separated by species in this study, and are hereafter referred to as Alexandrium spp. A 50× concentrated preserved water sample was counted for Alexandrium spp. cell abundance. If natural Alexandrium spp. abundance was less than

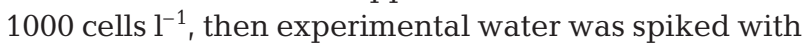
A. fundyense clone GTCA 28 (isolated from the southwest Gulf of Maine) to provide a final concentration of

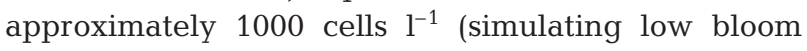
abundance). This was considered the minimum concentration necessary for acceptable counting statistics. Natural water Alexandrium spp. concentrations were augmented with GTCA 28 in 1998 on April 28 and on May 5 and 12, and in 1999 throughout the very moderate bloom season. When samples were augmented, cultured A. fundyense cells constituted between 25 and $100 \%$ of total available Alexandrium spp. cells. Clone GTCA 28 was cultured in an incubator at $14^{\circ} \mathrm{C}$ in $\mathrm{f} / 2-\mathrm{Si}$ with a $14: 10 \mathrm{~h}$ light:dark cycle. Toxicity of the A. fundyense culture, measured by high performance liquid chromatography with fluorescence detection (HPLC-FD, at the Institute for Marine Biosciences, National Research Council Canada, Halifax, Nova Scotia), was 20 to 25 pgSTXeq cell ${ }^{-1}$. Only exponentially growing cultures were used in experiments. Toxicity of natural Alexandrium spp., measured by HPLCFD from field samples of phytoplankton, was estimated at slightly lower levels of 10 to $15 \mathrm{pgSTXeq} \mathrm{cell}^{-1}$ (R. G. Campbell et al. unpubl. data). Toxin profiles (\% molar composition) revealed relatively more saxitoxin and less C-toxin in natural samples than in cultures, while other toxin profile differences were negligible.

Water samples were maintained at the temperature of the Damariscotta River estuary $\left(9\right.$ to $11^{\circ} \mathrm{C}$ during the study period) until experimental set-up. Replicate initial containers were preserved at the start of an experiment. One liter, $500 \mathrm{ml}$, or $280 \mathrm{ml}$ experimental containers were used, depending on prey concentrations and the number of grazers present. Triplicate experimental and control containers were prepared, and sufficient grazers were added to experimental containers to remove approximately $30 \%$ of the available prey, based on estimates of potential grazing rates and phytoplankton density (e.g., 30 to 40 Acartia hudsonica adult females $\mathrm{l}^{-1}, 5$ to 8 Calanus finmarchicus $\mathrm{C}^{-1} \mathrm{l}^{-1}$ ). Zooplankton were sorted directly from storage in natural seawater into experimental containers. Containers were placed on a grazing wheel rotating at $1 \mathrm{rpm}$, immersed in flowing seawater to maintain temperature $\left(9\right.$ to $\left.11^{\circ} \mathrm{C}\right)$. The duration of experiments was between 14 and $18 \mathrm{~h}$.

At the end of an experiment, animals were removed from experimental jars. Zooplankton condition was excellent, with no evidence of impairment, and mortality was very rare. Initial, control, and experimental suspensions were preserved by the following method: 30 or $50 \mathrm{ml}$ subsamples were preserved with $1 \%$ buffered formaldehyde, and larger subsamples of either $250 \mathrm{ml}$ (from $500 \mathrm{ml}$ and $280 \mathrm{ml}$ bottles) or $500 \mathrm{ml}$ (from 11 bottles) were concentrated 5-fold by reverse filtration through a $10 \mu \mathrm{m}$ mesh and preserved with $1 \%$ buffered formaldehyde.

Sample processing. Since Alexandrium spp. cell density was typically low, concentration techniques were used to allow counting of sufficient cells for feeding rate determinations. For Alexandrium spp. and other less abundant dinoflagellates and protozoa, 25 to $50 \mathrm{ml}$ of $5 \times$ concentrated samples were placed in settling chambers and allowed to settle for $24 \mathrm{~h}$. Samples prepared this way were then examined with epifluorescence and phase contrast microscopy. Depending on cell abundance and size, dominant diatoms were counted using either ambient or concentrated preserved solutions in a Sedgwick-Rafter chamber or a Palmer-Maloney chamber. Microflagellates $(<10 \mu \mathrm{m})$ did not contribute significantly to the available food complex and therefore were not considered. All counts were converted to cells $\mathrm{ml}^{-1}$, and algal growth and zooplankton clearance and ingestion rates were calculated with the equations of Frost (1972). Carbon content of microplankton food items in the samples was estimated from cell measurements with modified Strathmann equations for diatoms and dinoflagellates (Smayda 1978) and the carbon:volume ratios of Putt \& Stoecker (1989) for ciliates. 
Data analyses. Ambient diatom cells were usually 1 or more orders of magnitude more abundant than Alexandrium spp. cells. Therefore, for each experiment, comparisons of zooplankton clearance rates are more appropriate than ingestion rates. For each zooplankton species in each experiment, clearance rates for the major identifiable prey cell types were compared using 2-way ANOVA, and significant differences were clarified with Tukey post-hoc tests, using the SAS program (SAS Institute Inc, Cary, NC, USA). In addition, for each species of grazer, clearance rates among experiments were compared with unbalanced factorial ANOVA (global general linear model) using SAS.

Another measure of selective grazing is comparison of electivity indices (e.g., Ivlev 1961). In a review of electivity indices, Lechowicz (1982) recommended the selection coefficient $W_{\mathrm{i}}$ and electivity index $E_{\mathrm{i}}{ }^{*}$ of Vanderploeg \& Scavia $(1979 a, b)$ as the most useful, especially in cases where food types are not equally abundant in the food complex. Since Alexandrium spp. usually constituted $<5 \%$ of the available food in terms of carbon (Tables 1 \& 2), $W_{\mathrm{i}}$ and $E_{\mathrm{i}}{ }^{*}$ of Vanderploeg \& Scavia $(1979 a, b)$ were the most appropriate selectivity measures for the present study. The selection coefficients $W_{\mathrm{i}}$ for each major food type i in experiments were calculated from clearance (filtration) rates by

$$
W_{\mathrm{i}}=F_{\mathrm{i}} / \sum F_{\mathrm{i}}
$$

where $F_{\mathrm{i}}$ is the clearance rate of food type $\mathrm{i}$, and $\sum F_{\mathrm{i}}$ is the sum of clearance rates on all food types. The electivity index $E_{\mathrm{i}}{ }^{*}$ for each food type was then calculated by

$$
E_{\mathrm{i}}^{*}=\left[W_{\mathrm{i}}-(1 / \mathrm{n})\right] /\left[W_{\mathrm{i}}+(1 / \mathrm{n})\right]
$$

where $\mathrm{n}$ is the total number of food types in the food complex. This value can theoretically vary between -1 and 1, where 0 signifies no electivity (no selective grazing), negative numbers correspond to negative selection (avoidance), and positive numbers correspond to selection for species in the food complex.

\section{RESULTS}

Selective feeding in the presence of Alexandrium spp. cells was not consistent among experiments, and depended on the species of zooplankton grazer and cooccurring microplankton prey. Complete results of feeding experiments with Acartia hudsonica are shown in Table 3; as a visual aid, representative results from early, mid- and late bloom periods of 1998 and 1999 are depicted in Fig. 1. No clear pattern of either preference for or rejection of Alexandrium spp. is evident. Ciliates were often cleared at higher rates than other prey, and certain dinoflagellates (Ceratium spp.,
Dinophysis spp.) were frequently avoided, but Alexandrium spp. cells were in almost every case cleared at rates equivalent to those of ambient non-toxic phytoplankton (Fig. 1, Table 3). The significance of any differences in clearance rates on algal food species within each experiment (as determined by ANOVA/Tukey post-hoc tests) is listed in Table 3. Global unbalanced ANOVA of clearance rates did not reveal any significant differences among microplankton species in the A. hudsonica diet. $E_{\mathrm{i}}{ }^{*}$ (Table 3 ) were used for comparisons, and the results agreed with clearance rate comparisons, showing no consistent trend of positive or negative selective feeding on Alexandrium spp. cells. $W_{\mathrm{i}}$ is amenable to parametric inter-experiment comparisons, while $E_{\mathrm{i}}{ }^{*}$ is not (Lechowicz 1982). ANOVA/ Tukey tests of $W_{\mathrm{i}}$ ) suggested that ciliates (Laboea sp. and aloricate species) were selectively ingested ( $\mathrm{p}=$ 0.028).

During the spring of 1998 and of 1999, the species dominating the microplankton flora changed (Table 1, Table 2). In the early spring, small diatoms such as Skeletonema costatum chains (in 1998) and Chaetoceros socialis colonies (in 1999) dominated both cell abundance and carbon concentration in the available food complex at all stations, while Alexandrium spp. and other dinoflagellates were minor constituents. As the spring bloom of diatoms declined, dinoflagellates (including Alexandrium spp.) and ciliates contributed substantially to the total available carbon as determined by cell counts, particularly offshore (Table 2). This was primarily a result of the decline of diatoms, rather than a large increase in dinoflagellate concentrations. Regardless of changes in the food environment, Acartia hudsonica cleared Alexandrium spp. cells at rates similar to those on other phytoplankton species throughout the study period.

Nauplii of the barnacle Semibalanus balanoides consistently preferred abundant diatoms to dinoflagellates. Complete experimental results are shown in Table 4 and representative results in Fig. 2. ANOVA for individual experiments and global ANOVA of clearance rates and selectivity coefficients all indicated significant selective feeding on diatoms such as Chaetoceros spp. and Eucampia sp. ( $p<0.001)$. Electivity indices suggested that Alexandrium spp., other dinoflagellates, and ciliates were avoided as a group, since selection among dinoflagellates and ciliates was not common (Table 4). The abundance of barnacle nauplii declined rapidly in mid-May of both years, preceding the sharp decline in diatom abundance, so no information is available on naupliar feeding rates and selectivity in plankton assemblages dominated by dinoflagellates.

Calanus finmarchicus copepodites preferred diatoms when they were abundant in the food complex 


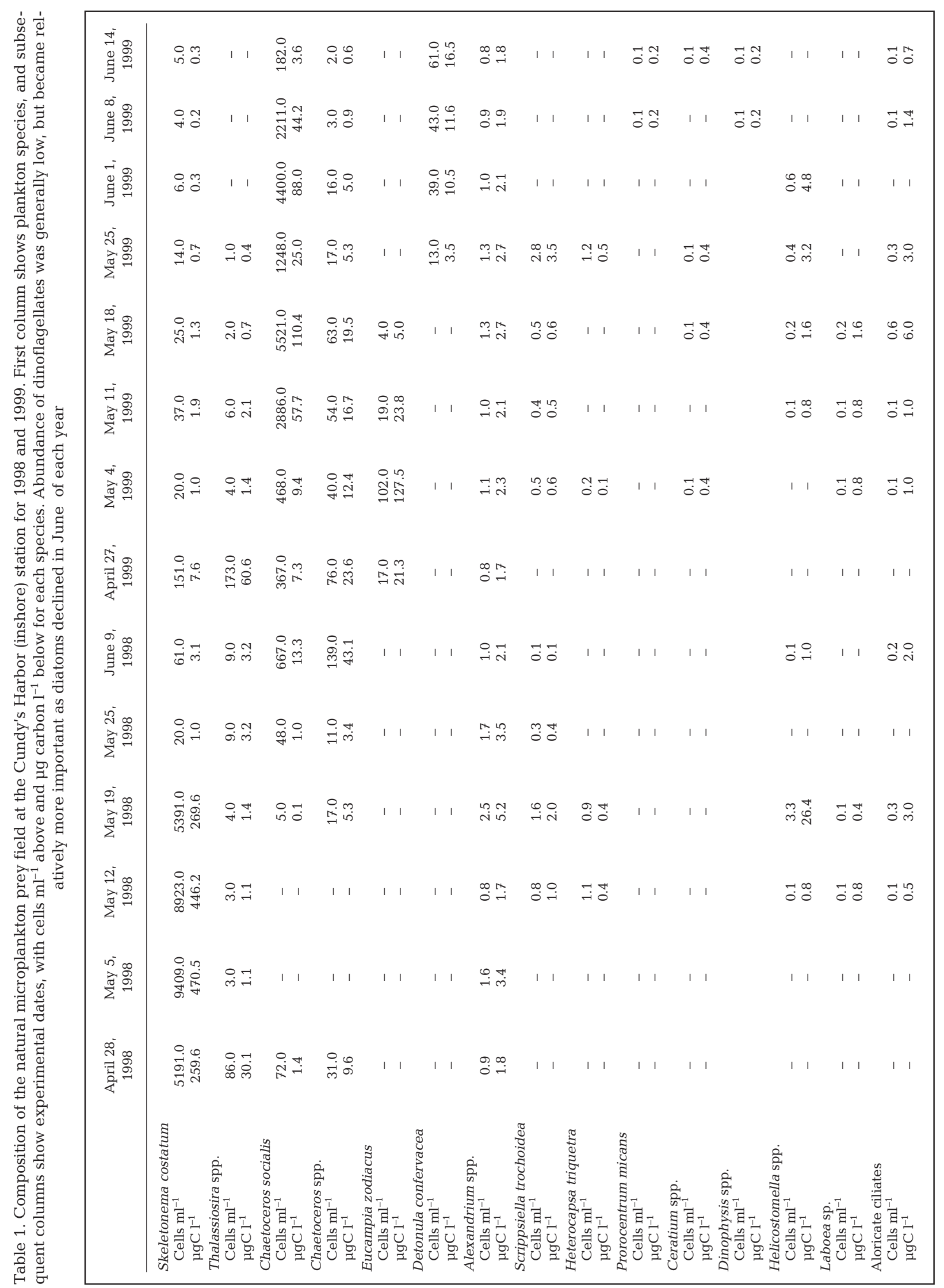


Table 2. Composition of the natural microplankton prey field at the offshore station for 1998 and 1999. See Table 1 for abbreviations. In 1999, diatoms virtually disappeared from the upper water column, resulting in low food levels dominated by dinoflagellates

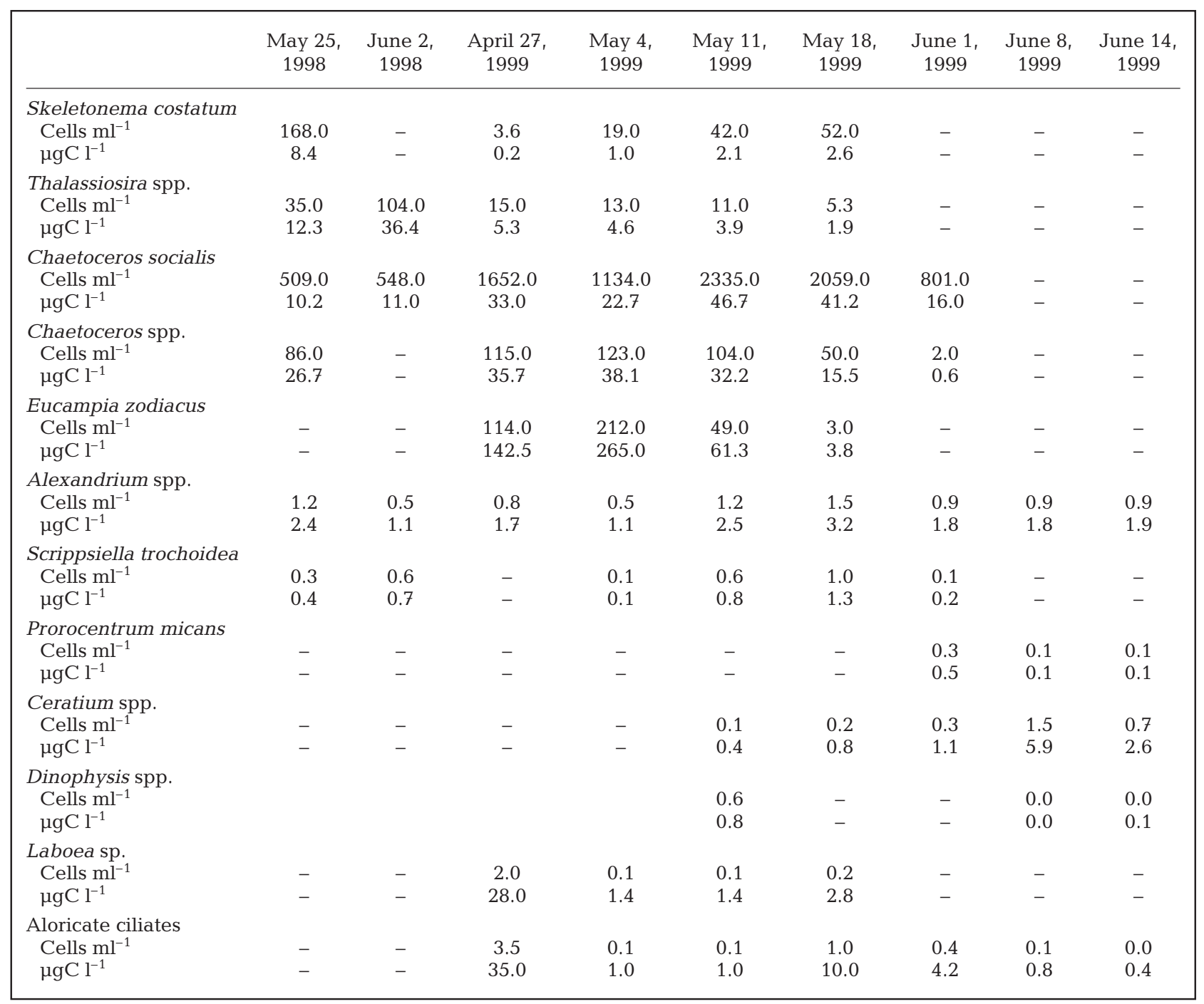

(complete results in Table 4, representative results in Fig. 3). In particular, small chain-forming and colonial diatoms (e.g., Chaetoceros socialis) were selectively ingested when present (Table 4). Electivity indices for Alexandrium spp. and most dinoflagellates and ciliates were generally negative or non-selective until June of both years, after diatoms had declined. At that point, with the absence of other prey, microplankton that had been generally avoided (dinoflagellates and ciliates) constituted the bulk of available food resources. The much lower abundance of available prey (Table 2) suggests probable food limitation at this time. Alexandrium spp. cells were not selectively avoided compared with other microplankton after the decline of the diatoms (Table 4). Ceratium spp. dinoflagellates were always avoided, probably owing to their large size and intractable shape. Global ANOVA of clearance rates from all experiments with $C$. finmarchicus indicated significant overall selective feeding on Chaetoceros spp. diatoms $(p<0.001)$. Global ANOVA of selectivity coefficients did not reveal significant differences $(\mathrm{p}=$ 0.08). Alexandrium spp. was not generally avoided relative to other dinoflagellates, which were either avoided or ingested as a group.

\section{DISCUSSION}

Selective feeding on various microplankton prey was apparent in most experiments (Tables $3 \& 4$ ). The zooplankton species examined in this study displayed varying degrees of avoidance of Alexandrium spp. and other dinoflagellates. Acartia hudsonica did not generally avoid Alexandrium spp., and Calanus finmarchicus 


\begin{tabular}{|c|c|c|c|c|c|c|c|c|c|c|c|c|c|c|c|c|}
\hline 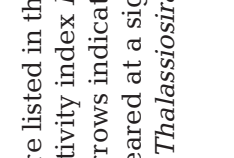 & 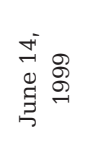 & $\begin{array}{ll}\qquad & \\
0 & 0 \\
0 & 0 \\
0 & 10 \\
+1 & 1 \\
0 & 11 \\
0 & 11 \\
0 & 11\end{array}$ & 1 & 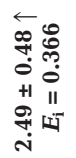 & $\begin{array}{ll}9 & 9 \\
8 & 8 \\
0 & 0 \\
0 & 0 \\
+1 & 1 \\
0 & 11 \\
0 & 11 \\
0 & 1\end{array}$ & 1 & 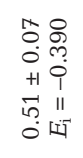 & $\begin{array}{ll}0 & 0 \\
0 & 0 \\
0 & =1 \\
+1 & 0 \\
0 & 11 \\
+1 & 11 \\
-1 & 41\end{array}$ & । & 1 & 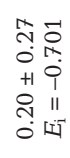 & 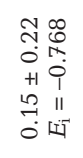 & $\begin{array}{ll}\infty & 0 \\
m & 0 \\
0 & 0 \\
+1 & 0 \\
+1 & 1 \\
\text { î. } & \| 1 \\
0 & 11\end{array}$ & 1 & 1 & \begin{tabular}{ll}
\multirow{2}{*}{} & 0 \\
0 & 0 \\
0 & 0 \\
+1 & 0 \\
+1 & 1 \\
0 & 11 \\
0 & 11 \\
0 & $1-1$
\end{tabular} \\
\hline 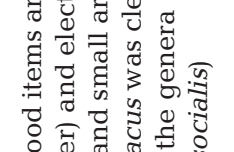 & 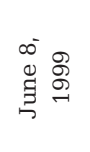 & $\begin{array}{ll}0 & 0 \\
0 & 0 \\
0 & 0 \\
+1 & 0 \\
0 & 0 \\
0 & 11 \\
0 & 11-1\end{array}$ & 1 & 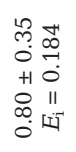 & 1 & 1 & 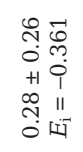 & 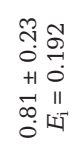 & । & 1 & $\begin{array}{l}10 \\
00 \\
0.9 \\
+10 \\
0 \\
011 \\
014\end{array}$ & 1 & $\begin{array}{ll} & \\
0 & 0 \\
0 & \infty \\
0 & 0 \\
+1 & 9 \\
+1 & 11 \\
0 & 11 \\
0 & 11-1\end{array}$ & 1 & 1 & $\begin{array}{ll}\infty & 0 \\
0 & 8 \\
0 & 0 \\
+1 & 0 \\
+1 & 11 \\
0 & 11 \\
0 & 1\end{array}$ \\
\hline 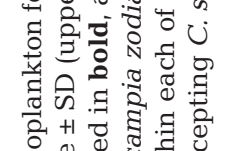 & 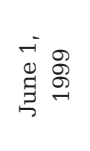 & 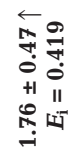 & 1 & 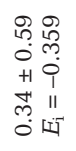 & 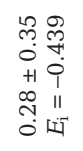 & I & 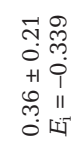 & 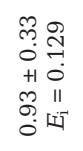 & । & 1 & 1 & 1 & 1 & $\begin{array}{ll}3 & 0 \\
0 & 9 \\
0 & 0 \\
0 & 0 \\
+1 & 0 \\
0 & 11 \\
0 & 11 \\
0 & 14\end{array}$ & 1 & 1 \\
\hline 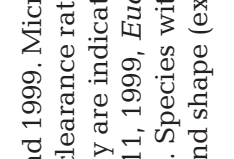 & 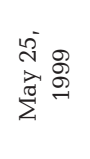 & 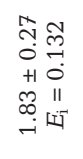 & 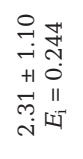 & 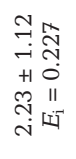 & 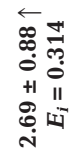 & 1 & 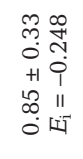 & 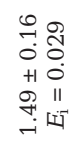 & 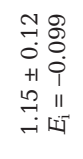 & 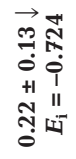 & 1 & 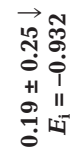 & 1 & 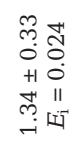 & \begin{tabular}{ll}
\multirow{H}{*}{} & $\infty$ \\
0 & $\infty$ \\
0 \\
+1 \\
0 \\
$\infty$ \\
$\stackrel{0}{1}$ \\
iv
\end{tabular} & $\begin{array}{ll}0 & 0 \\
\infty & 0 \\
0 & 0 \\
+1 & 0 \\
0 & 0 \\
0 & 11 \\
\rightarrow & 11\end{array}$ \\
\hline 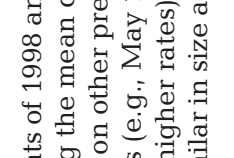 & 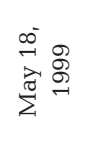 & $\begin{array}{ll}8 & 8 \\
0 & 0 \\
0 & -1 \\
+1 & 1 \\
0 & 11 \\
0 & 11 \\
0 & 01\end{array}$ & 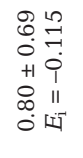 & 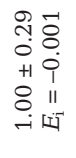 & 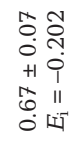 & 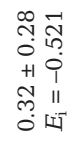 & 1 & 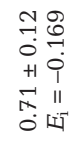 & 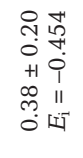 & 1 & 1 & 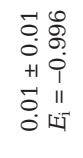 & 1 & 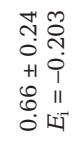 & 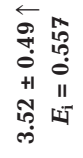 & 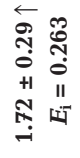 \\
\hline 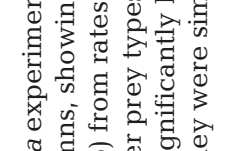 & 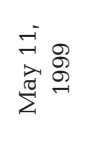 & 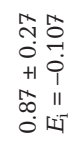 & $\begin{array}{ll}9 & 0 \\
3 & 0 \\
0 & 0 \\
+1 & 0 \\
0 & 11 \\
0 & 11 \\
-1 & 14\end{array}$ & 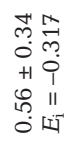 & 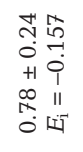 & 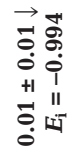 & 1 & 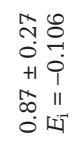 & 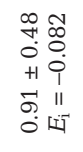 & 1 & 1 & 1 & 1 & 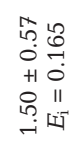 & 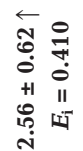 & 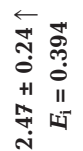 \\
\hline 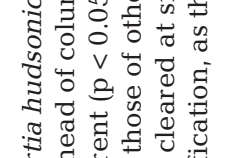 & 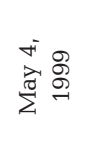 & 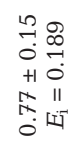 & $\begin{array}{l}\infty \\
\infty \\
0 \\
0 \\
0 \\
+1 \\
+1 \\
0 \\
0 \\
0 \\
0\end{array}$ & 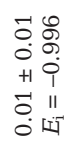 & 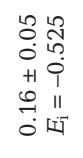 & 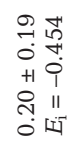 & 1 & $\begin{array}{ll}-7 & 0 \\
0 & 0 \\
0 & \infty \\
+1 \\
+1 \\
0 \\
0 \\
0 \\
0 \\
0\end{array}$ & 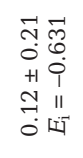 & 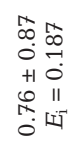 & I & 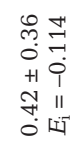 & $\begin{array}{ll}0 & 1 \\
0 & 0 \\
0 & \infty \\
++ & 1 \\
0 & 1 \\
0 & \| 1 \\
0 & 11-1\end{array}$ & । & 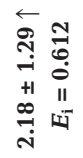 & 1 \\
\hline 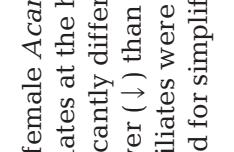 & 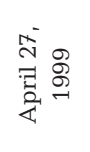 & 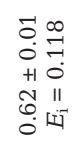 & 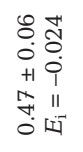 & 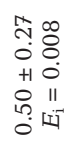 & 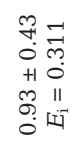 & 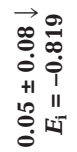 & 1 & 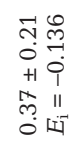 & 1 & 1 & 1 & 1 & I & 1 & 11 & I \\
\hline 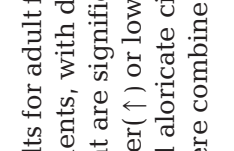 & 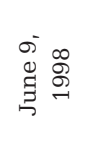 & 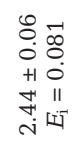 & 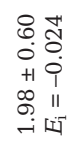 & 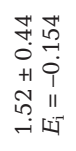 & 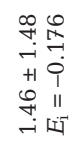 & 1 & 1 & 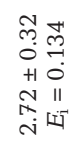 & 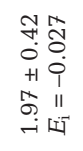 & 1 & 1 & 1 & 1 & 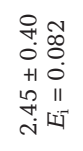 & 11 & 1 \\
\hline 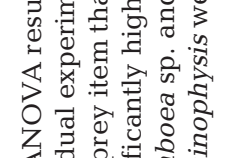 & 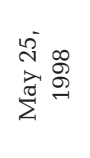 & 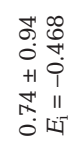 & 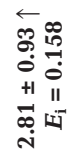 & 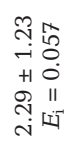 & 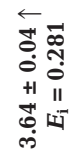 & 1 & 1 & 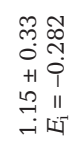 & 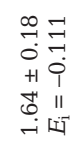 & 1 & I & 1 & I & 1 & 11 & 1 \\
\hline 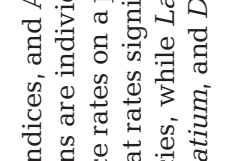 & 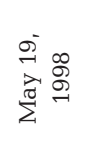 & $\begin{array}{ll}m & \\
3 & 0 \\
0 & -1 \\
++1 & 1 \\
1 & 11 \\
0 & 11 \\
0 & 014\end{array}$ & 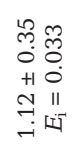 & 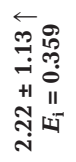 & 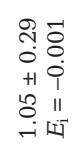 & 1 & 1 & 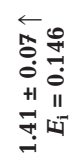 & 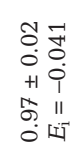 & 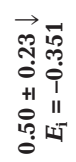 & 1 & 1 & I & 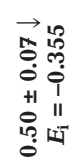 & 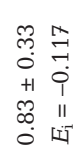 & 1 \\
\hline 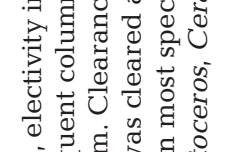 & 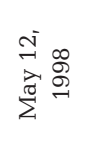 & 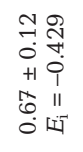 & 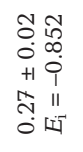 & I & I & 1 & 1 & 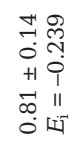 & 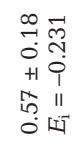 & 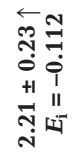 & 1 & 1 & 1 & 1 & 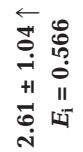 & 1 \\
\hline 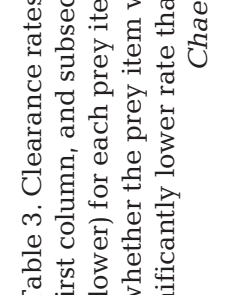 & 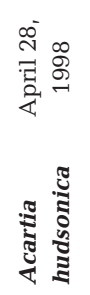 & 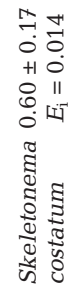 & 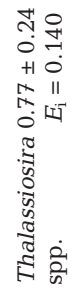 & 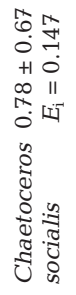 & 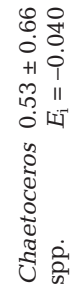 & 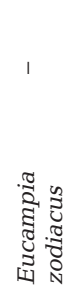 & 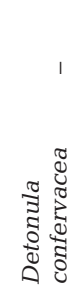 & 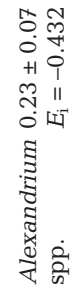 & 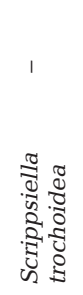 & 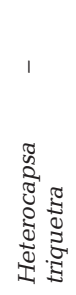 & 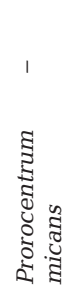 & 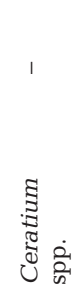 & 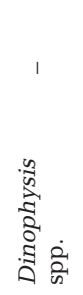 & 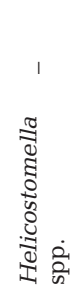 & 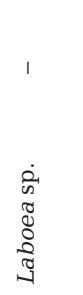 & 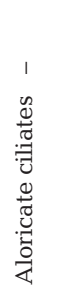 \\
\hline
\end{tabular}



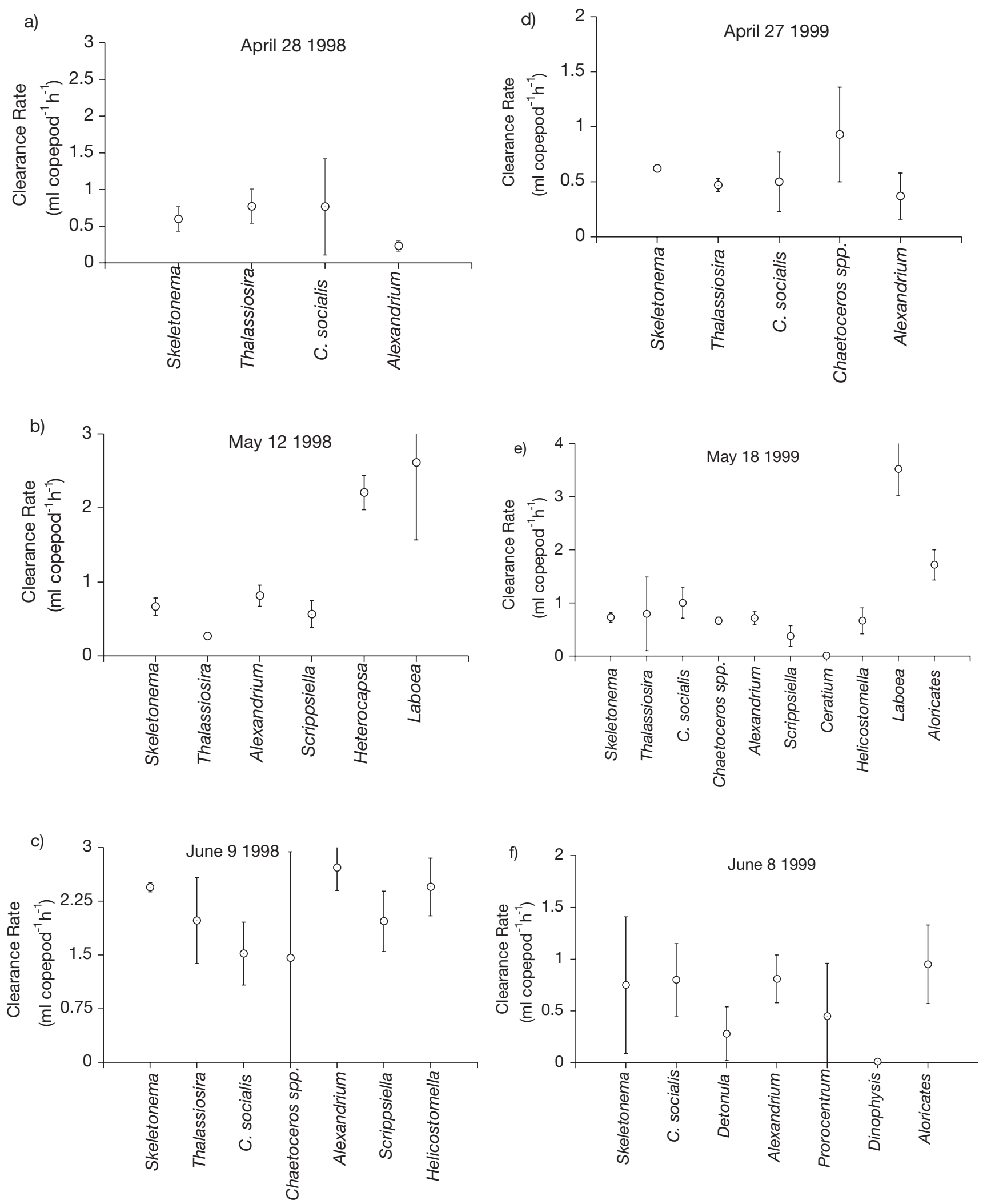

Fig. 1. Clearance rates (means $\pm \mathrm{SD}$ ) of Acartia hudsonica feeding on various microplankton, from early, mid-, and late spring experiments of $(\mathrm{a}, \mathrm{b}, \mathrm{c}) 1998$, and $(\mathrm{d}, \mathrm{e}, \mathrm{f})$ 1999. Alexandrium spp. cells were cleared at rates similar to those of other prey types. See Table 3 for details of clearance rates and significant differences as determined by ANOVA 


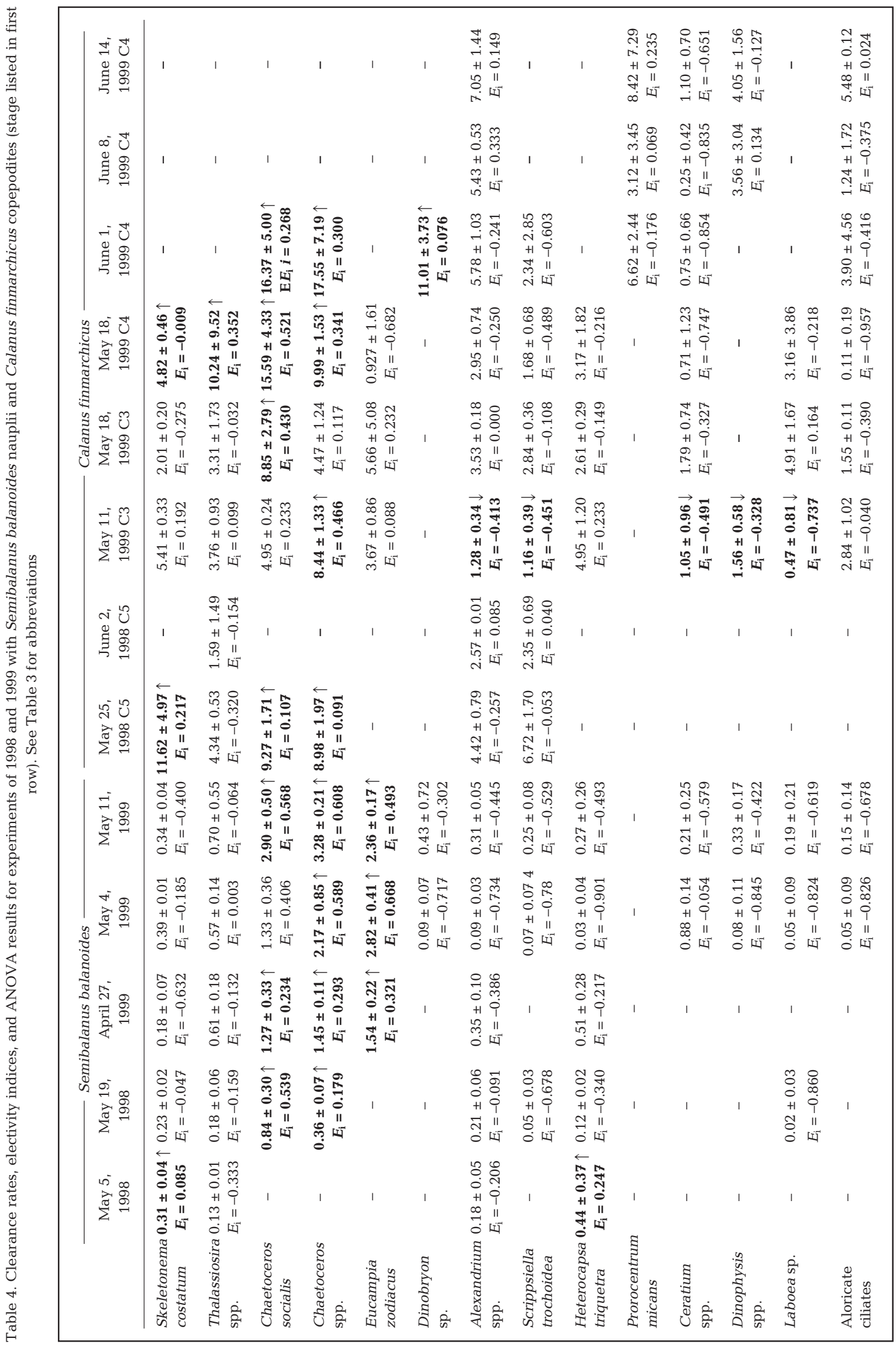



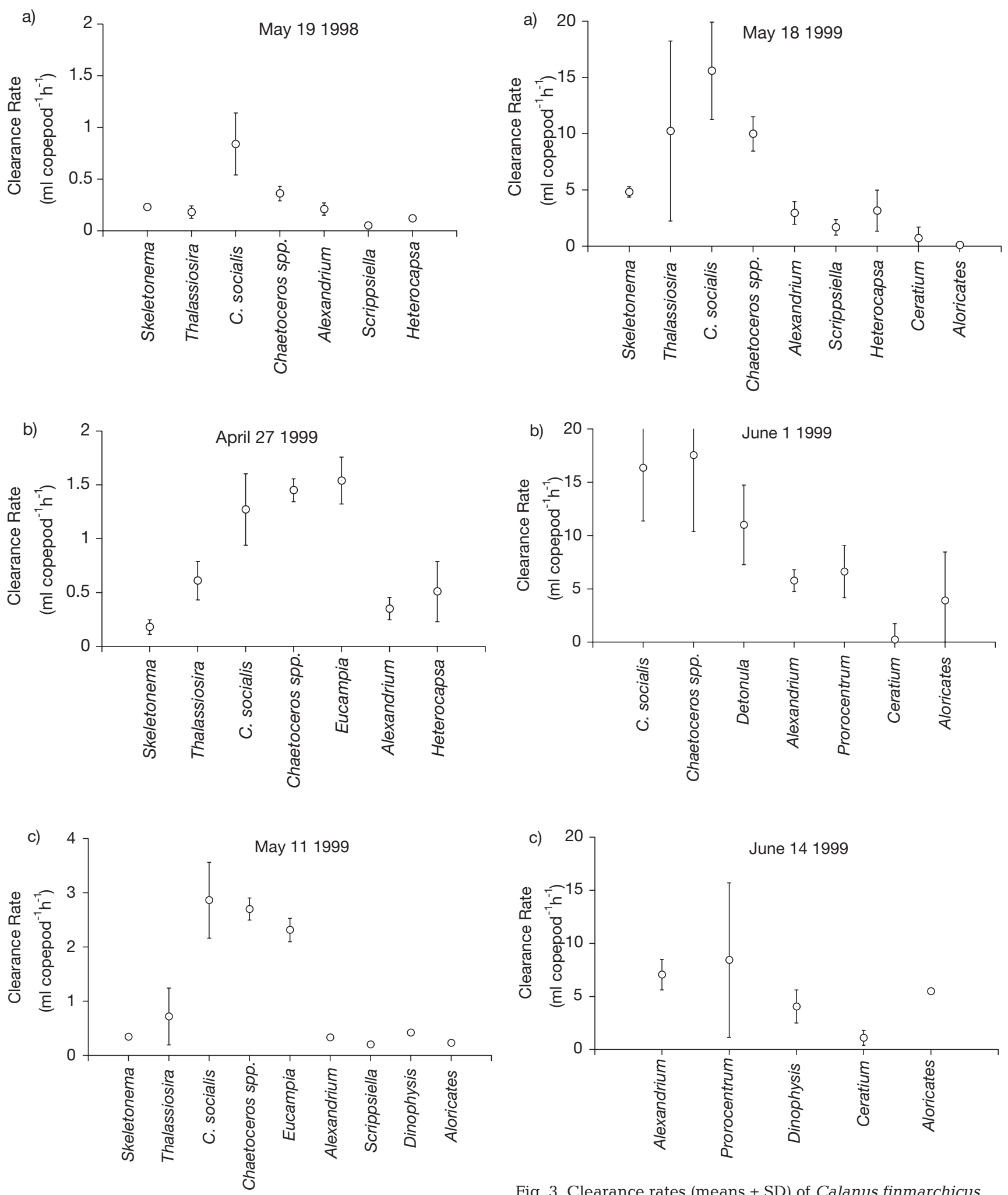

Fig. 2. Clearance rates (means $\pm \mathrm{SD}$ ) of nauplii of the barnacle Semibalanus balanoides, from (a) 1998 and (b,c) 1999. Diatoms were selectively ingested, but Alexandrium spp. cells were not discriminated from the remaining prey field. See Table 4 for significant differences

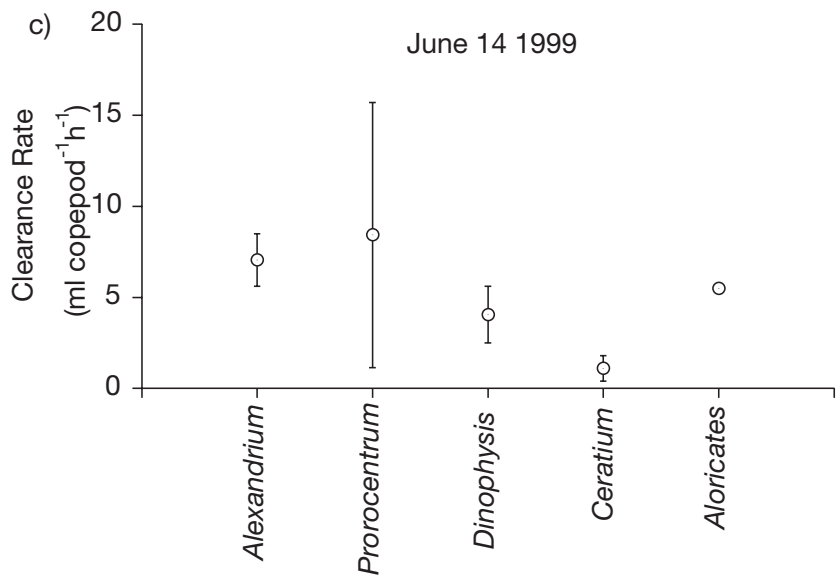

Fig. 3. Clearance rates (means $\pm \mathrm{SD}$ ) of Calanus finmarchicus from 1999. (a,b) Early to mid-spring; Chaetoceros spp. were cleared at higher rates than other microplankton. (c) After diatoms declined, Alexandrium spp. cells were cleared at rates similar to those of most other microplankton, while Ceratium spp. dinoflagellates were avoided 
and Semibalanus balanoides nauplii often avoided dinoflagellates but did not clearly discriminate between Alexandrium spp. and other dinoflagellates. These results contrast with laboratory studies that clearly demonstrate selective feeding by copepods, based on PSP toxin content (Teegarden 1999).

Acartia hudsonica did not display consistent patterns of selective feeding but frequently cleared ciliates at higher rates than other microplankton. On only 1 occasion (June 14, 1999) did A. hudsonica selectively feed on the most abundant particle or biomass dominant particle. In general no size-selective feeding behavior was identified for A. hudsonica. Preference for ciliate prey by the Acartidae has been noted in the past (Tiselius 1989, Wiadnyana \& Rassoulzadegan 1989), and may be due to mechanoreception of relatively large swimming prey (Jonsson \& Tiselius 1990). Maximum ingestion of ciliate prey corresponded to $<10 \%$ of total carbon intake (May 18, 1999) and was usually $<3 \%$. The low abundance of ciliates present in the natural water used in these experiments argues against consideration of ciliates as a quantitatively important food source during the spring bloom (this conclusion was also reached by Tiselius 1989 and Irigoien et al. 1998). Given the omnivorous nature of Acartidae, nonselective feeding on most prey is not surprising, but the ready inclusion of toxic Alexandrium spp. cells in the diet is less easily explained. The congener Acartia tonsa has displayed strong avoidance of toxic Alexandrium spp. in the laboratory and impairment when forced (by hunger) to ingest toxic Alexandrium spp. (Teegarden 1999).

Toxin content cell ${ }^{-1}$ may affect selective feeding by zooplankton on Alexandrium spp. (Turriff et al. 1995, Teegarden 1999). Although there were slight differences in estimated toxin content between laboratory cultures and field populations of Alexandrium spp. in this study, these differences were not substantial. Toxin content cell $^{-1}$ was in all cases in the normal range for the southwestern Gulf of Maine. Furthermore, all zooplankton species tested displayed consistent responses, whether the Alexandrium spp. present was from natural populations, laboratory cultures, or both sources. Observed patterns of selective (or nonselective) feeding are therefore probably not attributable to any fluctuation in Alexandrium spp. cellular toxin content.

It has been suggested that optimal diet theory may be a useful predictor of selective feeding behavior of suspension feeding zooplankton (Lehman 1976, DeMott 1989). In theory, toxic cells should be rejected because they are inimical (DeMott 1989), especially when alternative food is abundant and lower quality food items may be discarded without restricting intake. This was not the result obtained in this study, nor in other recent studies. Laboratory experiments with various species of calanoid copepods fed 2 food types (including toxic Alexandrium spp.) have shown that rejection of toxic Alexandrium spp. cells is maximal when they are abundant and alternative food is also abundant (Turriff et al. 1995, Teegarden 1999). In a previous study (Teegarden 1999), laboratory experiments with mixtures of several dinoflagellate species suggested that toxic Alexandrium spp. cells were never positively selected but could be consumed at rates equal to alternative non-toxic prey. The conclusions of the latter study suggested that the degree of selection displayed in mixtures is a function of the grazer's ability to tolerate PSP toxin ingestion. Grazers such as Acartia tonsa displayed severe impairment when feeding on monocultures of toxic Alexandrium spp. and displayed strong avoidance of toxic Alexandrium spp. in mixtures. The copepod Eurytemora herdmani, however, never displayed strong impairment when feeding on toxic Alexandrium spp. and further removed toxic Alexandrium spp. cells at rates equivalent to consumption of some alternative non-toxic food types. If Acartia hudsonica is not impaired by moderate PSP toxin ingestion, then that species may not be constrained to selectively avoid toxic cells.

Selection may also be impractical when Alexandrium spp. concentrations are very low. Even at the highest natural concentration of Alexandrium spp. encountered by Acartia hudsonica (2500 cells 1-1 , May 19, 1998), with reasonably high clearance rates (Table 3 ), ingestion was only $\sim 3$ cells $h^{-1}$. It is probable that such low rates of encounter and ingestion would not prompt selective feeding, particularly when scarce Alexandrium spp. cells co-occur with abundant alternative food. Natural field conditions usually contain diverse prey cell types, and relative abundance of species (both cell numbers and carbon concentrations) span orders of magnitude. Even though larger cells such as Thalassiosira spp. and dinoflagellates were probably recognized and 'handled', it is probable that smaller diatoms were processed simultaneously (e.g., as noted by Price \& Paffenhöfer 1986). This may have contributed to a masking effect whereby several chemical cues were experienced while handling multiple particles. The difficulty of recognizing and rejecting large particles in a complex mixture of smaller diatoms may have had an effect on the ability or willingness to feed selectively. Other examples of this potential phenomenon are the works of Frost (1977) and Sykes \& Huntley (1987), who have noted that indigestible plastic beads were consumed by copepods at higher rates when palatable phytoplankton were included in the food complex. The low frequency of encounter with Alexandrium spp. cells by zooplankton in this study may have been insufficient to trigger a selective feeding re- 
sponse, i.e., to develop a chemo- or mechano-receptive 'search image' for toxic cells. It is interesting to note that, on the 1 occasion when the carbon contribution of Alexandrium spp. cells to the total food complex was on the same order as other prey (May 25, 1998, Table 1), clearance of other prey (Thalassiosira spp., Chaetoceros spp., Table 3) was significantly higher.

Selection of food types was more apparent in experiments with Semibalanus balanoides nauplii and Calanus finmarchicus copepodites. The number of experiments conducted with $S$. balanoides nauplii was limited because of the brief duration of their dominance in the plankton during our study period. Their peak abundance coincided with maximal abundance of small diatoms (Skeletonema costatum in 1998 and Chaetoceros socialis in 1999), and their feeding behavior showed preference for small and medium size diatoms, and avoidance of most dinoflagellates and ciliates (Table 4). Very little has been published on the feeding processes of $S$. balanoides nauplii. This is somewhat surprising, since they are regularly abundant and even dominant in the net zooplankton of northeastern USA nearshore waters during the spring diatom bloom. White (1981) showed that $S$. balanoides nauplii could feed on toxic Alexandrium excavatum at very high concentrations ( 3 to $5 \times 10^{6} \mathrm{l}^{-1}$ ), but this cultured alga was the only food offered in his experiments.

Our results agree with earlier literature that has noted a preference for diatoms over flagellates in the diet of Semibalanus balanoides nauplii (Moyse 1963, Moyse \& Knight-Jones 1967). It has been suggested that $S$. balanoides nauplii cannot successfully develop without diatom food resources (Moyse 1963). This may be related to morphology; ultrastructural studies of feeding appendages suggest that $S$. balanoides nauplii are more efficient at feeding on colonial and chainforming diatoms than solitary flagellates (Rainbow \& Walker 1976). Regardless of mechanism, S. balanoides nauplii did not effectively graze on flagellates and ciliates in the present study, and displayed little or no selection among species in this group of motile prey, avoiding all more or less equally.

Much more work has been done on the diet and feeding processes of Calanus finmarchicus. Omnivory has been shown in numerous studies (see Harris 1996), and ciliates and dinoflagellates may be especially important in the diet of Calanus spp. after the decline of the spring diatom bloom (Ohman \& Runge 1994). The results of our study clearly suggest that C. finmarchicus preferentially cleared diatoms while they were dominant, and did not clear dinoflagellates and ciliates in proportion to their abundance. Selective feeding on diatoms during the spring bloom has been shown in other recent field studies (Meyer-Harms et al.
1999) and, as in our study, ciliates have been found to be quantitatively unimportant during the bloom because of their low concentrations (Tiselius 1989, Irigoien et al. 1998). After diatoms declined, the food resources in our experiments consisted almost entirely of dinoflagellates and ciliates, on which C. finmarchicus fed. Clearance rates on these food items were not significantly different before and after the disappearance of the diatoms. Thus this is not a case of 'prey switching' to dinoflagellates, but merely a greatly reduced food intake by $C$. finmarchicus after the demise of the spring bloom, under probable food-limiting conditions.

It is interesting that Alexandrium spp. was not selectively avoided relative to other available dinoflagellates. The dinoflagellate species most likely to co-occur with Alexandrium spp. at this time are Scrippsiella trochoidea (which is frequently found with Alexandrium spp. in the Gulf of Maine and generally follows the same population dynamics), Prorocentrum micans, Dinophysis spp., and Ceratium spp. There is reason to believe that this group is a grazer-resistant assemblage. S. trochoidea has been reported to be poor food for Calanus spp. and is frequently avoided (Huntley et al. 1986, Gill \& Harris 1987, Hassett \& Landry 1990). P. micans is often considered to be a beneficial food item in copepod diets, but experiments with mixtures of dinoflagellates have suggested that $P$. micans is not preferred over other dinoflagellates (Teegarden 1999). Dinophysis spp. have also been reported to be poor food or largely avoided by copepod grazers (Carlsson et al. 1995). Ceratium spp. are large $(>100 \mu \mathrm{m})$ and intractable dinoflagellates, and it has been suggested that the difficulty of handling and ingesting such prey affords a measure of protection from grazers (Harvey 1937, Granéli et al. 1993, Nejstgaard et al. 1994). Certainly, Ceratium spp. were avoided by all the grazers tested in our study.

\section{Ecological significance}

We specifically studied Alexandrium spp. blooms in the Casco Bay area, a region that suffers considerable economic hardship from seemingly moderate blooms (Shumway et al. 1988). Acartia hudsonica is usually the spring dominant zooplankton grazer in the nearshore waters of the southwestern Gulf of Maine. Natural Alexandrium spp. concentrations in this region are low, even at the peak of a bloom (on the order of $10^{3}$ cells $\mathrm{l}^{-1}$ ). If $A$. hudsonica dominates the zooplankton, because of its apparent non-selective feeding at these low Alexandrium spp. concentrations, removal of Alexandrium spp. from the water column would depend principally on grazer abundance (biomass). This general- 
ization apparently would not hold true if nauplii of Semibalanus balanoides were dominant nearshore, as is sometimes the case; their preference for diatoms may afford Alexandrium spp. and other dinoflagellates some protection. Offshore waters are dominated by other zooplankton species, such as Calanus finmarchicus and Pseudocalanus spp. Alexandrium spp. cells were often avoided by $C$. finmarchicus relative to abundant diatoms. Despite this, while $C$. finmarchicus clearance of Alexandrium spp. cells was lower than that of A. hudsonica on a weight-specific basis, it was not negligible, and removal of Alexandrium spp. again would depend principally on grazer biomass.

Questions remain regarding the possibility of toxinbased grazer deterrence by Alexandrium spp. While this has been shown in the laboratory (Teegarden 1999), the present field study did not always show evidence of such an effect. One possible explanation for this discrepancy is that chemical deterrence is concentration dependent. This type of defense has been hypothesized by Sykes (1991), who noted that toxic dinoflagellates (Protoceratium reticulatum) induced grazer avoidance only when they attained sufficient density (relative to co-occurring prey), and thus the chemical defense served principally to protect a bloom that had already formed, rather than allowing a sparse 'seed' population to grow free from grazing pressure. Concentration-dependent grazer inhibition has also been shown with the tintinnid ciliate Favella ehrenbergii feeding on toxic Alexandrium tamarense (Hansen 1989). Preliminary studies indicate that varying the concentrations of Alexandrium spp. in food mixtures affects the strength of copepod selective feeding behavior (Teegarden unpubl. data).

The southwestern Gulf of Maine harbors low Alexandrium spp. cell concentrations, but populations of Alexandrium spp. in other regions of the northwest Atlantic frequently attain much higher densities (e.g., Bay of Fundy, Martin \& White 1988, and St. Lawrence estuary, Therriault et al. 1985, Cembella et al. 1988). If selective grazing is concentration dependent, the significance of PSP toxin production for Alexandrium spp. grazer deterrence and thus bloom proliferation may differ in the various regions that experience blooms. In any environment during bloom initiation, when Alexandrium spp. concentrations are low and alternative prey are abundant, it is likely that zooplankton grazers can inhibit bloom formation if they are abundant and non-selective (e.g., Acartia hudsonica). Harmful blooms are more likely to form when grazers (such as Semibalanus balanoides nauplii) that avoid Alexandrium spp. are present, or when higher concentrations of Alexandrium spp. are attained before grazer biomass becomes sufficient to have a significant impact.
Acknowledgements. We would like to thank the staff of the Darling Marine Center, University of Maine, for their cheerful assistance in carrying out field and laboratory operations (in particular, Timothy Miller, Laboratory Coordinator, and Kevin Lapham and John Higgins, boat Captains). We also thank Dr Allan Cembella and Ms Nancy Lewis of the Institute for Marine Biosciences, National Research Council Canada, for toxin analysis of field and laboratory samples. This study was funded by NSF grant OCE-9726261.

\section{LITERATURE CITED}

Anderson DM (1997) Bloom dynamics of toxic Alexandrium species in the northeastern U.S. Limnol Oceanogr 42: $1009-1022$

Anderson DM, Morel FMM (1979) The seeding of two red tide blooms by the germination of benthic Gonyaulax tamarensis hypnocysts. Estuar Coast Mar Sci 8:279-293

Bautista B, Harris RP (1992) Copepod gut contents, ingestion rates and grazing impact on phytoplankton in relation to size structure of zooplankton and phytoplankton during a spring bloom. Mar Ecol Prog Ser 82:41-50

Carlsson P, Granéli E, Finenko G, Maestrini SY (1995) Copepod grazing on a phytoplankton community containing the toxic dinoflagellate Dinophysis acuminata. J Plankton Res 17:1925-1938

Cembella AD, Therriault JC, Béland P (1988) Toxicity of cultured isolates and natural populations of Protogonyaulax tamarensis from the St. Lawrence estuary. J Shellfish Res $7: 611-621$

Cowles TJ (1979) The feeding response of copepods from the Peru upwelling system: food size selection. J Mar Res 37:601-622

Cowles TJ, Olson RJ, Chisholm SW (1988) Food selection by copepods: discrimination on the basis of food quality. Mar Biol 100:41-49

Deitz A, Townsend DW (2000) Occurrence of Alexandrium ostenfeldii in the Gulf of Maine. Symposium on Harmful Marine Algae in the U.S. Marine Biological Laboratory, Woods Hole, MA, p 107 (abstract)

DeMott WR (1989) Optimal foraging theory as a predictor of chemically mediated food selection by suspension-feeding copepods. Limnol Oceanogr 34:140-154

Frost BW (1972) Effects of size and concentration of food particles on the feeding behavior of the marine planktonic copepod Calanus pacificus. Limnol Oceanogr 17: 805-815

Frost BW (1977) Feeding behavior of Calanus pacificus in mixtures of food particles. Limnol Oceanogr 22:472-491

Gifford DJ, Dagg MJ (1988) Feeding of the estuarine copepod Acartia tonsa Dana: carnivory vs. herbivory in natural microplankton assemblages. Bull Mar Sci 43:458-468

Gill CW, Harris RP (1987) Behavioural responses of the copepods Calanus helgolandicus and Temora longicornis to dinoflagellate diets. J Mar Biol Assoc UK 67:785-801

Granéli E, Olsson P, Carlsson P, Granéli W, Nylander C (1993) Weak 'top-down' control of dinoflagellate growth in the coastal Skagerrak. J Plankton Res 15:213-237

Hansen PJ (1989) The red tide dinoflagellate Alexandrium tamarense: effects on behavior and growth of a tintinnid ciliate. Mar Ecol Prog Ser 53:105-116

Harris RP (1996) Feeding ecology of Calanus. Ophelia 44:85-109

Harvey HW (1937) Note on selective feeding by Calanus. J Mar Biol Assoc UK 22:97-100

Hassett RP, Landry MR (1990) Seasonal changes in feeding 
rate, digestive enzyme activity, and assimilation efficiency of Calanus pacificus. Mar Ecol Prog Ser 62:203-210

Huntley M (1981) Nonselective, nonsaturated feeding by three calanid copepod species in the Labrador Sea. Limnol Oceanogr 26:831-842

Huntley M, Sykes P, Rohan S, Marin V (1986) Chemicallymediated rejection of dinoflagellate prey by the copepods Calanus pacificus and Paracalanus parvus: Mechanism, occurrence and significance. Mar Ecol Prog Ser 28: 105-120

Irigoien X, Head R, Klenke U, Meyer-Harms B, Harbour D, Niehoff B, Hirche HJ, Harris R (1998) A high frequency time series at weathership $M$, Norwegian Sea, during the 1997 spring bloom: feeding of adult female Calanus finmarchicus. Mar Ecol Prog Ser 172:127-137

Ivlev VS (1961) Experimental ecology of the feeding of fishes. Yale University Press, New Haven, p 19-115

Jonsson PR, Tiselius P (1990) Feeding behaviour, prey detection and capture efficiency of the copepod Acartia tonsa feeding on planktonic ciliates. Mar Ecol Prog Ser 60:35-44

Lam RK, Frost BW (1976) Model of copepod filtering response to changes in size and concentration of food. Limnol Oceanogr 21:490-500

Lechowicz MJ (1982) The sampling characteristics of electivity indices. Oecologia 52:22-30

Lehman JT (1976) The filter-feeder as an optimal forager, and the predicted shapes of feeding curves. Limnol Oceanogr 21:501-516

Martin JL, White AW (1988) Distribution and abundance of the toxic dinoflagellate Gonyaulax excavata in the Bay of Fundy. Can J Fish Aquat Sci 45:1968-1975

Meyer-Harms B, Irigoien X, Head R, Harris R (1999) Selective feeding on natural phytoplankton by Calanus finmarchicus before, during, and after the 1997 spring bloom in the Norwegian Sea. Limnol Oceanogr 44:154-165

Morey-Gaines G (1980) The ecological role of dinoflagellate blooms in the Los Angeles-Long Beach Harbor. PhD dissertation, University of Southern California, Los Angeles

Moyse J (1963) A comparison of the value of various flagellates and diatoms as food for barnacle larvae. J Cons 28 : 175-187

Moyse J, Knight-Jones EW (1967) Biology of Cirripede larvae. Proc Symp Crustac 2:595-611

Nejstgaard JC, Witte H, van der Wal P, Jacobsen A (1994) Copepod grazing during a mesocosm study of an Emiliania huxleyi (Prymnesiophyceae) bloom. Sarsia 79:369-377

Ohman MD, Runge JA (1994) Sustained fecundity when phytoplankton resources are in short supply: omnivory by Calanus finmarchicus in the Gulf of St. Lawrence. Limnol Oceanogr 39:21-36

Paffenhöfer GA, van Sant KB (1985) The feeding response of a marine planktonic copepod to quantity and quality of particles. Mar Ecol Prog Ser 27:55-65

Price HJ, Paffenhöfer GA (1986) Effects of concentration on the feeding of a marine copepod in algal monocultures and mixtures. J Plankton Res 8:119-128

Putt M, Stoecker DK (1989) An experimentally determined carbon:volume ratio for marine 'oligotrichous' ciliates from estuarine and coastal waters. Limnol Oceanogr 34: 1097-1103

Rainbow PS, Walker G (1976) The feeding apparatus of the barnacle nauplius larva: a scanning electron microscope study. J Mar Biol Assoc UK 56:321-326

Shaw BA, Andersen RJ, Harrison PJ (1997) Feeding deterrent and toxicity effects of apo-fucoxanthinoids and phycotox-

Editorial responsibility: Kenneth Sherman (Contributing Editor), Narragansett, Rhode Island, USA ins on a marine copepod (Tigriopus californicus). Mar Biol 128:273-280

Shumway SE, Sherman-Caswell S, Hurst JW (1988) Paralytic shellfish poisoning in Maine: monitoring a monster. J Shellfish Res 7:643-652

Smayda TJ (1978) From phytoplankters to biomass. In: Sournia A (ed) Phytoplankton manual. UNESCO, Paris, p 273-279

Smayda TJ (1980) Phytoplankton species succession. In: Morris I (ed) The physiological ecology of phytoplankton. University of California Press, Berkeley, p 493-570

Sykes PF (1991) Physiological-ecology and chemical-ecology of copepod-dinoflagellate interactions. PhD dissertation, University of California, San Diego

Sykes PF, Huntley ME (1987) Acute physiological reactions of Calanus pacificus to selected dinoflagellates: direct observations. Mar Biol 94:19-24

Teegarden GJ (1999) Copepod grazing selection and particle discrimination on the basis of PSP toxin content. Mar Ecol Prog Ser 181:163-176

Teegarden GJ, Cembella AD (1996) Grazing of toxic dinoflagellates, Alexandrium spp., by adult copepods of coastal Maine: implications for the fate of paralytic shellfish toxins in marine food webs. J Exp Mar Biol Ecol 196:145-176

Therriault JC, Painchaud J, Levasseur M (1985) Factors controlling the occurrence of Protogonyaulax tamarensis and shellfish toxicity in the St. Lawrence estuary: freshwater runoff and the stability of the water column. In: Anderson DM, White AW, Baden D (eds) Toxic dinoflagellates. Elsevier, New York, p 141-146

Tiselius P (1989) Contribution of aloricate ciliates to the diet of Acartia clausi and Centropages hamatus in coastal waters. Mar Ecol Prog Ser 56:49-56

Turner JT, Anderson DM (1983) Zooplankton grazing during dinoflagellate blooms in a Cape Cod embayment, with observations of predation upon tintinnids by copepods. Mar Ecol 4:359-374

Turner JT, Tester PA (1989) Zooplankton feeding ecology: nonselective grazing by the copepods Acartia tonsa Dana, Centropages velificatus De Oliveira, and Eucalanus pileatus Giesbrecht in the plume of the Mississippi River. J Exp Mar Biol Ecol 126:21-43

Turriff N, Runge JA, Cembella AD (1995) Toxin accumulation and feeding behaviour of the planktonic copepod Calanus finmarchicus exposed to the red-tide dinoflagellate Alexandrium excavatum. Mar Biol 123:55-64

van Alstyne KL (1986) Effects of phytoplankton taste and smell on feeding behavior of the copepod Centropages hamatus. Mar Ecol Prog Ser 34:187-190

Vanderploeg HA, Scavia D (1979a) Calculation and use of selectivity coefficients of feeding: zooplankton grazing. Ecol Model 7:135-149

Vanderploeg HA, Scavia D (1979b) Two electivity indices for feeding with special reference to zooplankton grazing. J Fish Res Board Can 36:362-365

Watras CJ, Garcon VC, Olson RJ, Chisholm SW, Anderson DM (1985) The effect of zooplankton grazing on estuarine blooms of the toxic dinoflagellate Gonyaulax tamarensis. J Plankton Res 7:891-908

White AW (1981) Marine zooplankton can accumulate and retain dinoflagellate toxins and cause fish kills. Limnol Oceanogr 26:103-109

Wiadnyana NN, Rassoulzadegan F (1989) Selective feeding of Acartia clausi and Centropages typicus on microzooplankton. Mar Ecol Prog Ser 53:37-45

Submitted: August 10, 2000; Accepted: February 2, 2001

Proofs received from author(s): July 20, 2001 